Check for updates

Cite this: RSC Adv., 2019, 9, 26338

\title{
Aqueous carbofuran removal using slow pyrolyzed sugarcane bagasse biochar: equilibrium and fixed- bed studies $\uparrow$
}

\begin{abstract}
Vineet Vimal, Manvendra Patel (D) and Dinesh Mohan (D) *
Herein, biochar was produced by the slow pyrolysis of sugarcane bagasse at $500^{\circ} \mathrm{C}$ in absence of oxygen. The resulting sugarcane bagasse biochar (SB500) was characterized and used for aqueous carbofuran sorptive removal. Batch carbofuran sorption studies were accomplished to ascertain the influence of solution $\mathrm{pH}$, contact time, temperature $\left(25,35\right.$ and $\left.45^{\circ} \mathrm{C}\right)$ and adsorbate/adsorbent concentration. SB500 adsorbed more carbofuran at low pH values and less carbofuran at high $\mathrm{pH}$ values. The necessary sorption equilibrium, kinetic and thermodynamic parameters were determined. The equilibrium isotherm data were fitted to the Freundlich, Langmuir and Temkin models. The Langmuir equation best fitted the experimental sorption data. The maximum Langmuir adsorption capacity of $18.9 \mathrm{mg} \mathrm{g}^{-1}$ was obtained at $\mathrm{pH} 6.0$ and $45^{\circ} \mathrm{C}$. The enthalpy change $\left(\Delta H^{\circ}\right)$, entropy change $\left(\Delta S^{\circ}\right)$ and Gibbs free energy $\left(\Delta G^{\circ}\right)$ were evaluated. The fixed-bed carbofuran sorption studies were carried out using the optimum parameters determined via the batch studies. The necessary fixed-bed design parameters were obtained. Carbofuran desorption and SB500 regeneration were successfully achieved. About $96 \%$ of the total carbofuran was successfully desorbed from the exhausted biochar using $20 \mathrm{~mL}$ ethanol in $10 \mathrm{~mL}$ increments. Moreover, a possible carbofuran adsorption mechanism has been proposed. A number of interactions including (1) hydrogen bonding of the protonated and neutral carbofuran to biochar, (2) carbofuran sorption onto biochar via $\pi-\pi$ electron donor-acceptor interactions and (3) carbofuran diffusion into the biochar pores were considered to explain the sorption mechanism. The batch and fixed-bed sorption results demonstrate that the sugarcane bagasse biochar (SB500) can be effectively used for the sustainable removal and recovery of carbofuran from water.
\end{abstract}

Received 4th March 2019 Accepted 27th May 2019

DOI: $10.1039 / \mathrm{c} 9 \mathrm{ra01628g}$

rsc.li/rsc-advances

\section{Introduction}

Water is of prime importance for the sustenance of life on Earth and most exploited among all the available natural resources. ${ }^{1}$ Water quality deterioration results in its limited use by human beings and other organisms. ${ }^{2}$ Any adverse change in the biological, chemical, and physical properties of water results in harmful effects on human health and other living beings. ${ }^{3}$ Pesticides are considered to be toxic water contaminants. Their large scale use for agricultural as well as non-agricultural purposes has resulted in their outreach to different environmental matrices. ${ }^{4}$ Pesticides are used for killing specific target organisms; however they also affect the non-target organisms including soil microorganisms, birds and human beings. Moreover, pesticides may cause cancer, chronic kidney disease, sterility in male and females,

School of Environmental Sciences, Jawaharlal Nehru University, New Delhi 110067, India. E-mail: dm_1967@hotmail.com; Fax: +91-11-26704616; Tel: +91-11-26704616 $\dagger$ Electronic supplementary information (ESI) available. See DOI: 10.1039/c9ra01628g genotoxicity, reproductive, physiological, neurological, behavioral and endocrine disorders. ${ }^{5,6}$ Carbofuran (2,3-dihydro-2,2-dimethylbenzofuranyl-7- $N$-methylcarbamate; trade name furadan) is an organic pesticide. ${ }^{7}$ It is used as a broad spectrum insecticide, acaricide and nematicide. ${ }^{8-13}$ The maximum contamination level goal (MCLG) of carbofuran in drinking water is $0.04 \mathrm{mg} \mathrm{L}{ }^{-1} \cdot{ }^{14}$ However, carbofuran is now being used quite often as it has low persistence as compared to organochlorines (OC) and is less toxic than neurotoxic organophosphates (OP). ${ }^{15}$ The $\mathrm{EC}_{50}$ value of carbofuran as determined using the microtox bioassay of $V$. fischeri is $20.5 \mathrm{mg} \mathrm{L}{ }^{-1} \cdot{ }^{16}$ Carbofuran is highly toxic to bees, birds, and fish $^{\mathbf{1 7}}$ and can kill fishes, wildlife and invertebrates. ${ }^{\mathbf{1 7}}$ Moreover, carbofuran causes sensory system overstimulation by hindering acetyl-cholinesterase. ${ }^{17}$ Overexposure to carbofuran results in abdominal cramping, blurred vision, coma, convulsions, headache, nausea, tremors, and weakness. ${ }^{17}$

Photolysis, ${ }^{18-21}$ ozonation, ${ }^{22,23}$ UV-irradiation, ${ }^{24}$ advanced oxidation, ${ }^{22}$ nanofiltration and osmosis ${ }^{25}$ and adsorption ${ }^{26-29}$ are currently used for aqueous carbofuran removal. Activated carbon sorption in water is the most frequently employed 
<smiles>CNC(=O)Oc1cccc2c1OC(C)(C)C2</smiles>

Fig. 1 Chemical structure of carbofuran.

method as compared to other methods; $;^{30,31}$ however, the use of activated carbon is not very cost effective; thus, there is an urgent requirement to find low-cost, sustainable and effective adsorbents for the removal of carbofuran at varying concentrations from water. The application of biochar in the removal of inorganic and organic contaminants is gaining attention. ${ }^{32,33}$ Biochar provides a sustainable option as it possesses the characteristics, including high surface area and adsorbate recovery and regeneration of the exhausted biochar, of activated carbon. ${ }^{34}$ Fast pyrolyzed ${ }^{35}$ biochar, a by-product obtained during bio-oil production, has also been used for contaminant removal. ${ }^{36}$ Slow and fast pyrolyzed biochars have been used to remediate arsenic, ${ }^{36}$ fluoride, ${ }^{37,38}$ aniline and nitrobenzene, ${ }^{39}$ nitrates,${ }^{38}$ lead ${ }^{40,41}$ cadmium,${ }^{40}$ pesticides,${ }^{42,43}$ nickel, ${ }^{44}$ pharmaceuticals, ${ }^{43,45,46}$ and phenols. ${ }^{47}$ Other slow and fast pyrolyzed biochars used for organic and inorganic contaminants have also been reviewed. ${ }^{32}$ Biochars obtained from rice husks ${ }^{27}$ and tea waste ${ }^{28}$ have been successfully applied for aqueous carbofuran removal. These studies were conducted in an acidic medium in the batch mode. The fixed-bed studies are essential for scaling up the process. Thus, both the batch and the fixed-bed studies have been undertaken in the present investigation.
In India, the current biomass availability is $\sim 500$ million metric tons per year. ${ }^{48,49}$ India is the second largest producer of sugarcane (Saccharum officinarum) in the world after Brazil. During 2015-2016, India produced 348 million tonnes of sugarcane ${ }^{50}$ Furthermore, the residue production percentage of the sugarcane crop is $33 \% .^{51}$ Thus, the total bagasse production in 2015-16 was $\sim 115$ million tonnes. Bagasse is commonly used as a boiler fuel and also in paper manufacturing. Thus, herein, sugarcane bagasse-derived biochar (SB500) was obtained and successfully used as a sustainable environmental approach for the sorptive removal of carbofuran.

\section{Materials and methods}

Carbofuran $\left(\mathrm{C}_{12} \mathrm{H}_{15} \mathrm{NO}_{3}\right)$ of $98 \%$ purity was obtained from Sigma-Aldrich, India (Fig. 1).

\subsection{Sugarcane bagasse biochar (SB500) development}

Sugarcane bagasse was collected from Bhikhanpur village $\left(28^{\circ} 44.828^{\prime} \mathrm{N}\right.$ and $77^{\circ} 27.656^{\prime} \mathrm{E}$ with $698 \mathrm{ft}$ elevation), Ghaziabad, Uttar Pradesh, India. It was cut into small pieces and sun dried for a week. It was then slow pyrolyzed at different temperatures. The biochar obtained at temperatures higher or lower than $500{ }^{\circ} \mathrm{C}$ was not very effective for carbofuran removal as compared to biochar obtained at $500{ }^{\circ} \mathrm{C}$. Thus, dried sugarcane bagasse was pyrolyzed in the absence of oxygen at $500{ }^{\circ} \mathrm{C}$ at $10{ }^{\circ} \mathrm{C} \min ^{-1}$ heating rate and $30 \mathrm{~min}$ dwell time in a muffle furnace (Thermolyne model 33900-45). The developed biochar was used for carbofuran sorption. The development process of sugarcane bagasse biochar (SB500) is summarized in Fig. 2.

\subsection{Characterization}

2.2.1 Fourier transform infrared (FTIR) spectroscopy. Functional groups on the SB500 surface were determined using Varian 7000 Fourier Transform Infrared Spectrometer. The

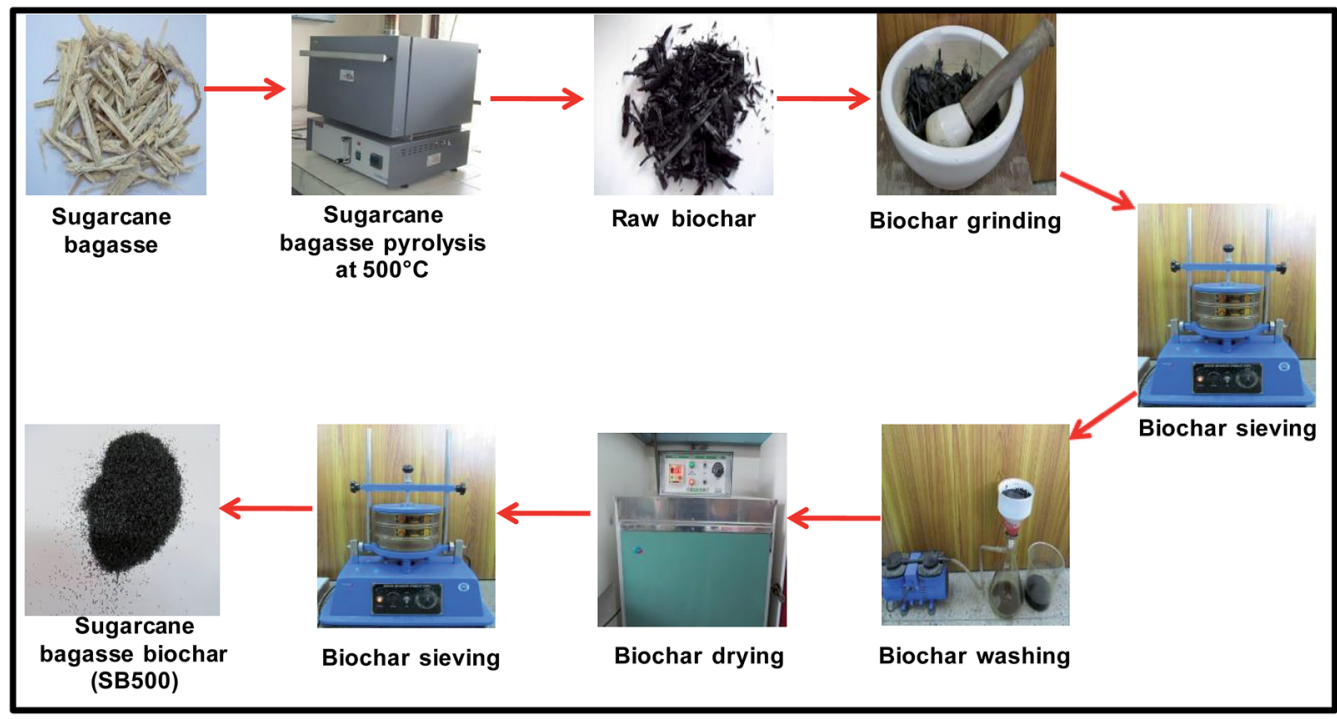

Fig. 2 Sugarcane bagasse biochar (SB500) development. 
powdered SB500 sample pellet was prepared using a hydraulic press. The FTIR spectra of SB500 were obtained in the transmittance mode in the $400-4000 \mathrm{~cm}^{-1}$ range.

2.2.2 X-ray powder diffraction (XRD). PANalytical (model X'Pert PRO) X-ray powder diffraction system was employed to obtain the X-ray diffraction pattern of SB500. Cu-K $\alpha(\lambda=1.54 \AA)$ radiation at $45 \mathrm{kV}$ and $40 \mathrm{~mA}$ was used. The XRD pattern of SB500 was obtained in the $2 \theta$ range of $5-90^{\circ}$ (where $\theta$ is the diffraction angle) with the $2^{\circ} \mathrm{min}^{-1}$ scan speed and the step size of $0.05^{\circ}$.

2.2.3 Scanning electron microscopy (SEM). The surface morphology and pore structure of SB500 were probed using the Zeiss EVO 40 scanning electron microscope (operating voltage $=20000 \mathrm{kV} \mathrm{mA}{ }^{-1}$ ). A small quantity of SB500 was rested on a double sided carbon tape placed on an aluminum stub. A thin layer of gold nanoparticles was coated on the SB500 sample surface to make it conductive. The sample surface was examined at different magnifications.

2.2.4 Surface area measurement. The pore volume, pore size and BET surface area $\left(S_{\mathrm{BET}}\right)$ of SB500 were determined using the ASAP 2020 Micromeritics surface area analyzer. The surface area was calculated by the $\mathrm{N}_{2}$ adsorption-desorption on biochar at the boiling point of nitrogen.

2.2.5 Elemental analysis. The LECO CHNS-932 analyzer was used to determine the carbon, hydrogen, and nitrogen contents in SB500.

\subsection{Sorption studies}

2.3.1 Batch sorption studies. The carbofuran stock solution (1000 $\mathrm{mg} \mathrm{L}^{-1}$ ) was prepared in double distilled water. A number of fresh carbofuran solutions (1-100 $\mathrm{mg} \mathrm{L}^{-1}$ ) were prepared using the stock solution and used in batch sorption studies. The $\mathrm{pH}$ was maintained using $0.1 \mathrm{~N} \mathrm{NaOH}$ and $0.1 \mathrm{~N}$ $\mathrm{HNO}_{3}$. The effect of solution $\mathrm{pH}$ on carbofuran $\left(10 \mathrm{mg} \mathrm{L}^{-1}\right)$ adsorption was studied in the pH range of 2-8 at SB500 dose of $2 \mathrm{~g} \mathrm{~L}^{-1}$ and $25{ }^{\circ} \mathrm{C}$. The Thermo-Scientific ORION 5 STAR pH meter was used for the $\mathrm{pH}$ measurements. The equilibrium sorption experiments were carried out using $2.0 \mathrm{~g} \mathrm{~L}^{-1}$ SB500. The adsorbent/adsorbate suspension was kept in airtight containers, which were placed in a water bath shaker at a predecided constant temperature. The containers were agitated at 80-120 rpm until the equilibrium was reached. The equilibrium time was however decided by carrying out kinetics experiments. Once the sorption equilibrium was reached, all the samples were syringe-filtered (pore size $0.2 \mu \mathrm{m}$ ) prior to spectrophotometric analysis. The carbofuran concentrations in the samples were determined using the double beam PerkinElmer Lambda 35 UV-visible spectrophotometer at the $275 \mathrm{~nm}$ wavelength. The equilibrium sorption capacity $q_{\mathrm{e}}\left(\mathrm{mg} \mathrm{g}^{-1}\right)$ was determined using eqn (1).

$$
q_{\mathrm{e}}=\left[\left(C_{\mathrm{o}}-C_{\mathrm{e}}\right) \times V\right] / M
$$

where $q_{\mathrm{e}}\left(\mathrm{mg} \mathrm{g}^{-1}\right)$ is the amount of carbofuran adsorbed per gram of the SB500, $V$ is the volume of the carbofuran solution $(\mathrm{L}), M$ is the biochar mass $(\mathrm{g}), C_{\mathrm{o}}\left(\mathrm{mg} \mathrm{L}^{-1}\right)$ and $C_{\mathrm{e}}\left(\mathrm{mg} \mathrm{L}^{-1}\right)$ are the initial and equilibrium aqueous carbofuran concentrations, respectively. All the batch equilibrium and dynamic sorption studies were accomplished in duplicate, and the average of the two measurements was reported.

\subsubsection{Thermodynamic parameters}

The Gibbs free energy change $\left(\Delta G^{\circ}\right)$, enthalpy change $\left(\Delta H^{\circ}\right)$ and entropy change $\left(\Delta S^{\circ}\right)$ were evaluated to examine the carbofuran adsorption process. $\Delta G^{\circ}, \Delta H^{\circ}$ and $\Delta S^{\circ}$ were calculated using eqn (2) and (3). ${ }^{52}$

$$
\begin{aligned}
\Delta G^{\circ} & =-R T \ln K \\
\ln K & =\frac{\Delta S^{\circ}}{R}-\frac{\Delta H^{\circ}}{R T}
\end{aligned}
$$

where $T$ is the absolute temperature, $R$ is the universal gas constant, and $K$ is the Langmuir isotherm constant $\left(\mathrm{L} \mathrm{mg}^{-1}\right)$.

2.3.2 Fixed-bed adsorption studies. Laboratory scale fixedbed adsorption studies are required for scaling up the process. The lab scale fixed-bed parameters were used for the actual large scale fixed-bed reactor design. The fixed-bed was designed using the optimum parameters determined via the batch sorption studies. An acrylic column of $40 \mathrm{~cm}$ length and $20 \mathrm{~mm}$ diameter was used. About $6.0 \mathrm{~g}$ sugarcane bagasse biochar (SB500) was made into a slurry using hot water to remove any dust or ash. The slurry was then filled in the column to form a fixed bed supported by glass wool. A schematic of the fixedbed set-up is shown in Fig. 3. The carbofuran solution (initial concentration $=4.5 \mathrm{mg} \mathrm{L^{-1 }}$ ) was fed into this fixed-bed at 1 $\mathrm{mL} \min ^{-1}$ flow rate under gravity till the exhaustion point was reached.

The concentration of the aqueous adsorbate changes as a function of time. In an ideal breakthrough curve, the effluent concentration of carbofuran $\left(C_{\mathrm{f}}\right)$ passing through the sugarcane bagasse biochar (SB500) fixed bed is almost zero or negligible at the beginning of the operation. However, in real practice, the effluent concentration $\left(C_{\mathrm{f}}\right)$ is not always zero. ${ }^{47}$ Thus, in the ideal breakthrough curve, the carbofuran effluent concentration $\left(C_{\mathrm{f}}\right)$ and the total treated water quantity $\overline{V_{\mathrm{e}}}$ crossing per unit cross sectional area very much depend on (i) the total effluent quantity per unit cross sectional area at the breakpoint $\overline{V_{\mathrm{b}}}$ and (b) the nature of the breakthrough curve obtained between $\overline{V_{\mathrm{b}}}$ and $\overline{V_{\mathrm{x}}}$ (Fig. 3). $C_{\mathrm{x}}$ and $C_{\mathrm{b}}$ are the effluent concentrations corresponding to $\overline{V_{\mathrm{x}}}$, and $\overline{V_{\mathrm{b}}}$. The fixed zone length $(\delta)$ is a part of the bed when the carbofuran concentration is decreased from $C_{\mathrm{x}}$ to $C_{\mathrm{b}} \cdot{ }^{54}$

The breakthrough point was obtained after percolating $260 \mathrm{~mL}$ carbofuran solution (260 minutes after the column run started at the $1 \mathrm{~mL} \mathrm{~min}^{-1}$ flow rate). Similarly, the exhaustion point was obtained after percolating $1080 \mathrm{~mL}$ of carbofuran solution (1080 minutes after the column run started at 1 $\mathrm{mL} \min ^{-1}$ flow rate).

The primary adsorption zone (PAZ) establishment time $\left(t_{\mathrm{x}}\right)$, PAZ downward movement time required to travel its own length in the fixed-bed $\left(t_{\delta}\right)$, carbon bed depth $(D)$ and time ratio $\left(\frac{\delta}{D}\right)$, fractional capacity (f), PAZ length $(\delta)$, bed volume, percent 


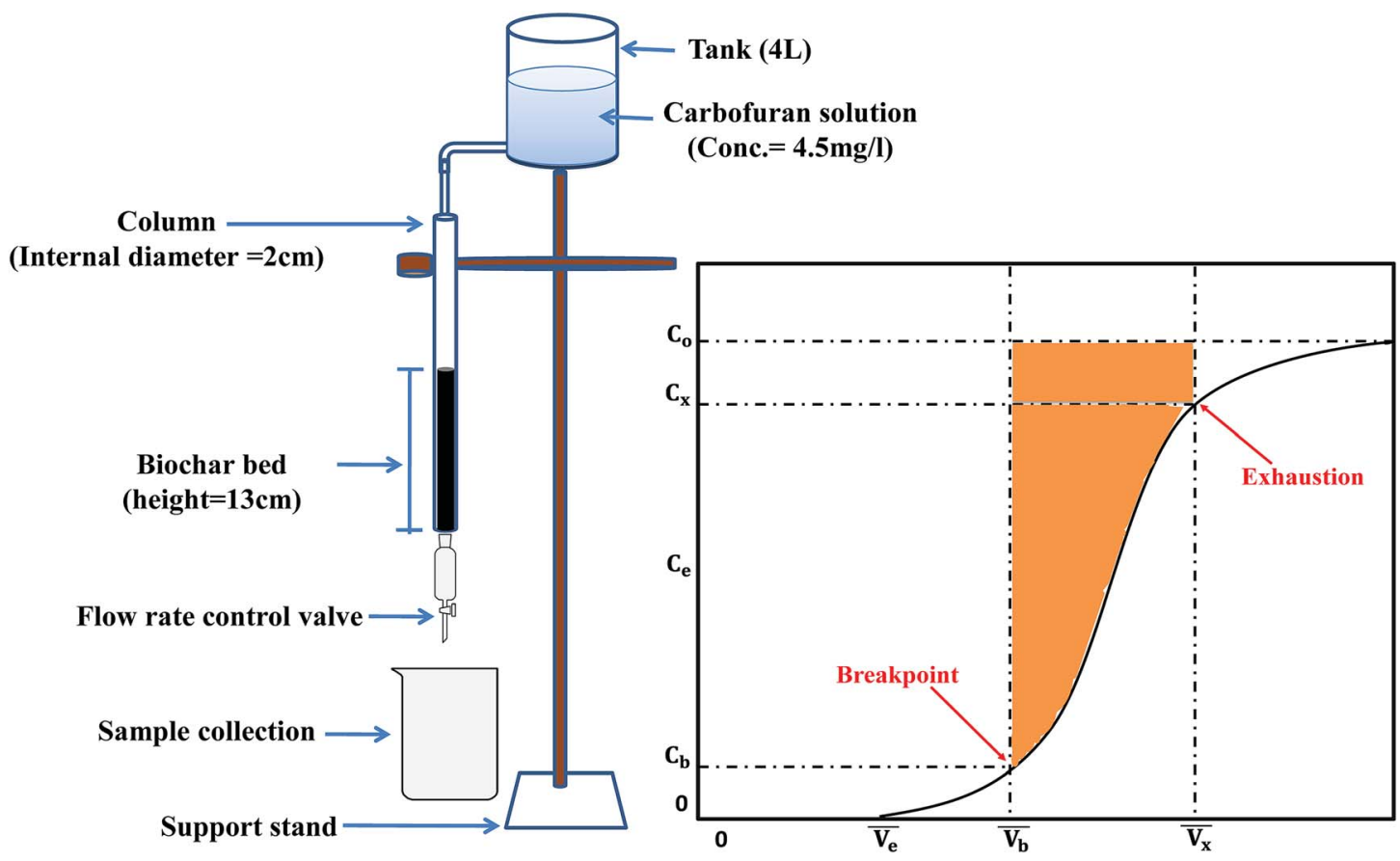

Fig. 3 Sugarcane bagasse biochar (SB500) fixed-bed setup. ${ }^{47,54}$

saturation, empty bed contact time (EBCT), and biochar utili- $\quad$ The EBCT was calculated by using the eqn (10), zation rate were calculated using eqn (4)-(9), ${ }^{47,54}$

$$
t_{\mathrm{x}}=\frac{\overline{V_{\mathrm{x}}}}{F_{\mathrm{m}}}
$$

where $F_{\mathrm{m}}$ is the mass flow rate.

$$
\begin{gathered}
t_{\delta}=\frac{\overline{V_{\mathrm{x}}}-\overline{V_{\mathrm{b}}}}{F_{\mathrm{m}}} \\
\frac{\delta}{D}=\frac{t_{\delta}}{t_{\mathrm{x}}-t_{\mathrm{b}}}
\end{gathered}
$$

where $t_{\mathrm{b}}$ is the time taken for initial PAZ formation.

$$
\begin{gathered}
f=1-\frac{t_{\mathrm{b}}}{t_{\delta}} \\
\delta=D\left(1-\frac{t_{\mathrm{b}}}{t_{\mathrm{x}}}\right) \\
\text { Percent saturation }=\frac{D+\delta(f-1)}{D} \times 100
\end{gathered}
$$

The biochar adsorption capacity was calculated by taking the total area between the influent and effluent to the breakthrough point divided by the biochar dose utilized in the fixed-bed development. Similarly, the column capacity was calculated by determining the total area to the point where the effluent plot meets the effluent, divided by the amount of biochar used in the study. ${ }^{47,54}$

The Empty Bed Contact Time (ЕВCT) model was used to determine the empty bed contact time (EBCT) and biochar usage. ${ }^{47,54}$ EBCT is the ratio of the empty bed volume to the flow rate. It is described as the total time when the carbofuran influent is in contact with the biochar bed in the column. ${ }^{47,54}$ where

$$
\text { Bed volume }=\frac{\text { weight of biochar }(\mathrm{kg})}{\text { biochar bulk density }\left(\frac{\mathrm{kg}}{\mathrm{m}^{3}}\right)}
$$

EBCT was determined using the bed depth (eqn (12)).

$$
\mathrm{EBCT}=\frac{\text { bed depth }}{\text { linear velocity }}
$$

The biochar usage rate was calculated using eqn (13). ${ }^{47,54}$

Biochar usage rate $\left(\mathrm{kg} \mathrm{L}^{-1}\right)=\frac{\text { weight of biochar in column }(\mathrm{g})}{\text { breakthrough volume }(\mathrm{L})}$

\section{Results and discussion}

\subsection{Biochar characterization}

The surface morphology of a material is best described by investigating the SEM images of the material obtained at different magnifications. These images depict the shape and size of the pores and grooves present on the biochar surface. The SEM images of sugarcane bagasse biochar (SB500) are 
shown in Fig. 4(a-d). These images show an irregular amorphous surface with porous structures. The images [Fig. 4(a and b)] clearly show fibrous structures as well as some polygonal structures [Fig. 4(c)]. These structures may have originated due to the melting and fusion process of lignin and other small molecules including pectin and inorganic compounds. Similar observations have been reported for sugar cane straw- and pine wood-derived biochars. ${ }^{55,56}$ The surface area $\left(S_{\mathrm{BET}}\right)$, pore volume and average pore width are $148.23 \mathrm{~m}^{2} \mathrm{~g}^{-1}, 0.048 \mathrm{~m}^{3} \mathrm{~g}^{-1}$ and $2.11 \mathrm{~nm}$, respectively. Biochar is quite stable in both acidic and basic solutions. The ultimate and proximate analysis results of the SB500 biochar are presented in Table 1.

Powder XRD is an important characterization tool that usually provides vital information about the mineralogy and crystal structure of a material. ${ }^{57,58}$ The XRD pattern of SB500 is shown in Fig. 5. The SB500 diffractogram is characterized by three sharp peaks obtained at $43.69^{\circ}(d=2.071), 50.95^{\circ}(d=$ $1.792 \AA)$, and $72.55^{\circ}(d=1.301 \AA)$. The peaks at $43.69^{\circ}$ and $50.95^{\circ}$ are attributed to calcite, whereas the peak at $72.55^{\circ}$ is due to silica. ${ }^{59}$

FTIR also plays an important role in the identification of various aliphatic, olefinic and aromatic functional groups including alcohols, organic acids, lactones, phenolic compounds, olefins, ketones, and quinones. ${ }^{60}$ The FTIR spectra of unloaded and carbofuran-loaded SB500 were obtained in the range of 500-4000 $\mathrm{cm}^{-1}$ (Fig. 6). Carbofuran-loaded and unloaded SB500 spectra display various oxygen-containing $(\mathrm{C}=$ $\mathrm{O}, \mathrm{C}-\mathrm{O}$, and $-\mathrm{OH})$ and other $(\mathrm{C}-\mathrm{H}$ and $\mathrm{C}=\mathrm{C})$ surface groups. Unloaded SB500 exhibited peaks at 1419.60 and $1458.75 \mathrm{~cm}^{-1}$, corresponding to aromatic ring modes, ${ }^{61} 1558.54 \mathrm{~cm}^{-1}$ for alkene $(\mathrm{C}=\mathrm{C})$ stretching, ${ }^{62} 1772.57 \mathrm{~cm}^{-1}$ for $\mathrm{C}=\mathrm{O}$ stretching
Table 1 Proximate and ultimate analyses of sugarcane bagasse biochar

\begin{tabular}{lc}
\hline Properties & Values \\
\hline $\mathrm{pH}$ & 6.82 \\
$\mathrm{pH}_{\text {pzc }}$ & 5.9 \\
Electrical conductivity $\left(\mu \mathrm{S} \mathrm{cm}^{-1}\right)$ & 33.3 \\
Ash content $(\%)$ & 4.7 \\
Moisture content $(\%)$ & 5.7 \\
Percentage yield & 25 \\
Carbon $(\%)$ & 74.9 \\
Hydrogen $(\%)$ & 2.3 \\
Oxygen $(\%)$ & 5.3 \\
Molar H/C & 0.37 \\
Molar O/C & 0.05 \\
BET surface area $\left(\mathrm{m}^{2} \mathrm{~g}^{-1}\right)$ & 148.23 \\
Pore volume $\left(\mathrm{cm}^{3} \mathrm{~g}^{-1}\right)$ & 0.048
\end{tabular}

bands, ${ }^{63} 2360.86 \mathrm{~cm}^{-1}$ due to carbon dioxide, ${ }^{64,65} 2897.07 \mathrm{~cm}^{-1}$ for aliphatic $\mathrm{C}-\mathrm{H}$ bond stretching, ${ }^{66-68}$ and $3651.39 \mathrm{~cm}^{-1}$ for non-H-bonded hydroxyl and phenolic $\mathrm{O}-\mathrm{H}$ stretching (Fig. 6). ${ }^{69-71}$ After carbofuran adsorption, few new peaks appeared at $815.88,1600.91,1701.21$, and $3649.31 \mathrm{~cm}^{-1}$. The peak at $815.88 \mathrm{~cm}^{-1}$ corresponds to the out-of-plane $\mathrm{C}-\mathrm{H}$ deformation of aromatic ring. ${ }^{72,73}$ The peak at $1600.91 \mathrm{~cm}^{-1}$ corresponds to the $\mathrm{C}=\mathrm{C}$ bond in the ring structure. ${ }^{62}$ The peak at $1701.21 \mathrm{~cm}^{-1}$ could be due to the the amide $\mathrm{C}=\mathrm{O}$ stretching mode present in the carbofuran molecule (Fig. 6). ${ }^{62}$ The reason for the tiny shift in the hydroxyl bond peak from 3651.39 to $3649.31 \mathrm{~cm}^{-1}$ is possibly due to the carbofuran bonding on the SB500 surface.

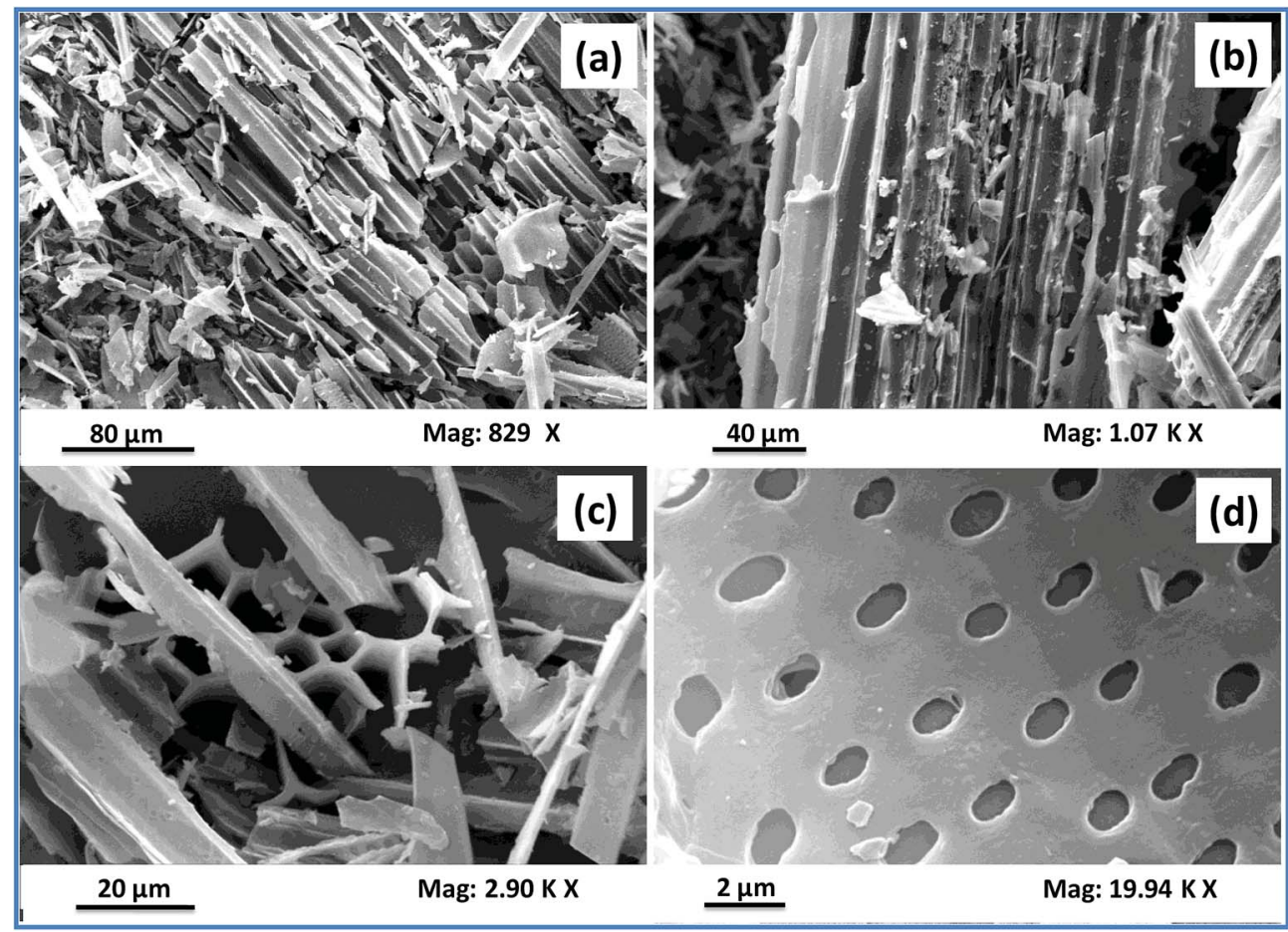

Fig. 4 SEM images of SB500 at (a) $829 \times$, (b) $1.07 \mathrm{k} \times$, (c) $2.90 \mathrm{k} \times$ and (d) $19.94 \mathrm{k} \times$ magnifications. 


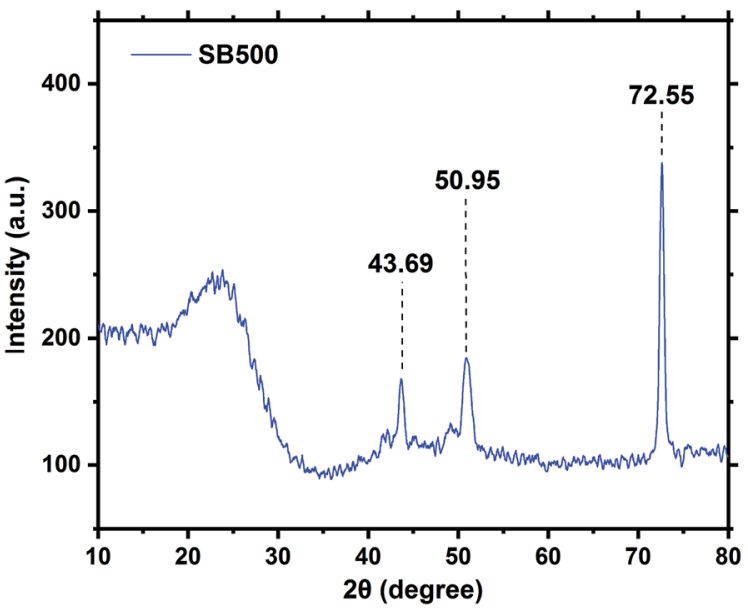

Fig. 5 X-ray diffractogram of SB500.

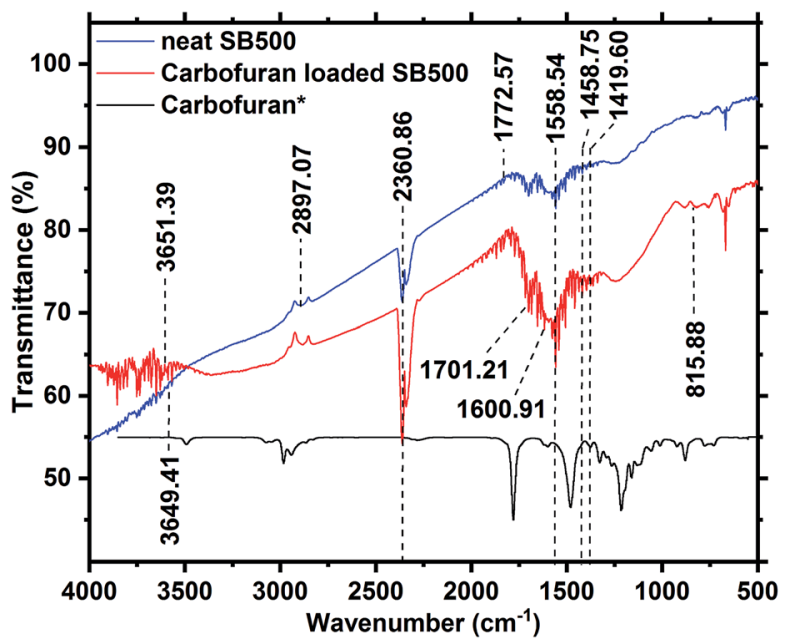

Fig. 6 FTIR spectra of SB500 before and after carbofuran adsorption (carbofuran IR data adopted with permission from NIST Library ${ }^{53}$ ).

\subsection{Effect of $\mathrm{pH}$ on carbofuran removal and sorption mechanism}

The surface functional groups on an adsorbent affect the overall adsorption process. These functional groups determine biochar's surface charge characteristics and provide various biochar-carbofuran interactions. ${ }^{74}$ The point of zero charge $\left(\mathrm{pH}_{\mathrm{pzc}}\right)$ measured for SB500 is 5.99 (Table 1). Thus, the biochar's surface is net negatively charged at $\mathrm{pH}>\mathrm{pH}_{\mathrm{pzc}}$ and positively charged at $\mathrm{pH}<\mathrm{pH}_{\mathrm{pzc}}$. The solution $\mathrm{pH}$ also affects the speciation of carbofuran in the solution by protonation or deprotonation. The acid dissociation constant $\mathrm{p} K_{\mathrm{a}_{1}}$ of the protonated carbofuran is close to 3.78 ; thus, at acidic $\mathrm{pH}$ values $<3.78$, protonated carbofuran is the predominant form. At a solution $\mathrm{pH}>3.78\left(\mathrm{pH}>\mathrm{p} K_{\mathrm{a}_{1}}\right)$, the unprotonated (neutral) carbofuran dominates (Scheme 1).

The carbofuran adsorption versus solution $\mathrm{pH}$ is shown in Fig. 7. Carbofuran removal decreased slightly from $56 \%$ to $51 \%$ with an increase in the initial solution $\mathrm{pH}$ from 2 to 6 . This suggests that both the protonated and the neutral carbofuran forms can be adsorbed. In a strongly acidic medium, protonation occurs at the carbonyl oxygen of carbofuran's urethane functional group, generating a cationic species. This cation experiences both H-bonding interactions with the surface oxygen sites that are neutral and repulsive electrostatic forces from the biochar's net positive surface charge at $\mathrm{pH}$ values below the biochar's zero-point charge $(\sim 6.0)$. Neutral carbofuran experiences $\mathrm{H}$-bonding from $\mathrm{pH} 2$ to 6 . A further increase in the solution $\mathrm{pH}$ from 6.0 to 8.0 caused the carbofuran removal to decrease from $51 \%$ to $40 \%$ (Fig. 7). The equilibrium $\mathrm{pH}$ also increased with an increase in the solution $\mathrm{pH}$ except at $\mathrm{pH}$ 2. This decrease in the carbofuran removal from $\mathrm{pH} 6$ to 8 might be related to the loss of acidic surface $-\mathrm{OH}$ groups as the surface is increasingly deprotonated above its $\mathrm{pH}_{\mathrm{ZPC}}$. Neutral carbofuran is a better $\mathrm{H}$-bond acceptor rather than a $\mathrm{H}$-bond donor. As the stronger surface $\mathrm{H}$-bond donor sites (more acid -OH groups) are deprotonated, the net $\mathrm{H}$-bonding perhaps becomes less attractive for carbofuran. The protonated carbofuran acts as a strong $\mathrm{H}$-bond donor and $\mathrm{H}$-bond acceptor and has two H-bond donor sites: the proton on its carbonyl carbon and the proton on nitrogen. The latter becomes a stronger $\mathrm{H}$ bond donor due to resonance, causing an increased positive charge at nitrogen. The ether oxygen in the five-membered ring is still a H-bond acceptor. Thus, H-bonding contributes to the adsorption of protonated carbofuran even at $\mathrm{pH}<\mathrm{pH}_{\mathrm{ZPC}}$ where the surface has a net positive charge.

The deprotonation of carbofuran does not play a role in adsorption in the pH 2-9 range. Carbofuran is a very weak base, as indicated by its $\mathrm{p}_{\mathrm{a}_{2}}$ value of 11.96 (Scheme 1). Even at $\mathrm{pH}$ 9.0 , very little deprotonated carbofuran exists in the solution to play a role, and the biochar surface is now more negatively charged.<smiles>CNC(=O)Oc1cccc2c1OC(C)(C)C2</smiles><smiles>CN(C(=O)Oc1cccc2c1OC(C)(C)C2)[C@@H]1C[C@@H]2C[C@@H]21</smiles><smiles></smiles>

$\mathrm{pKa}_{1}=\mathbf{3 . 7 8}$

Carbofuran

Scheme 1 Carbofuran speciation in solution. 


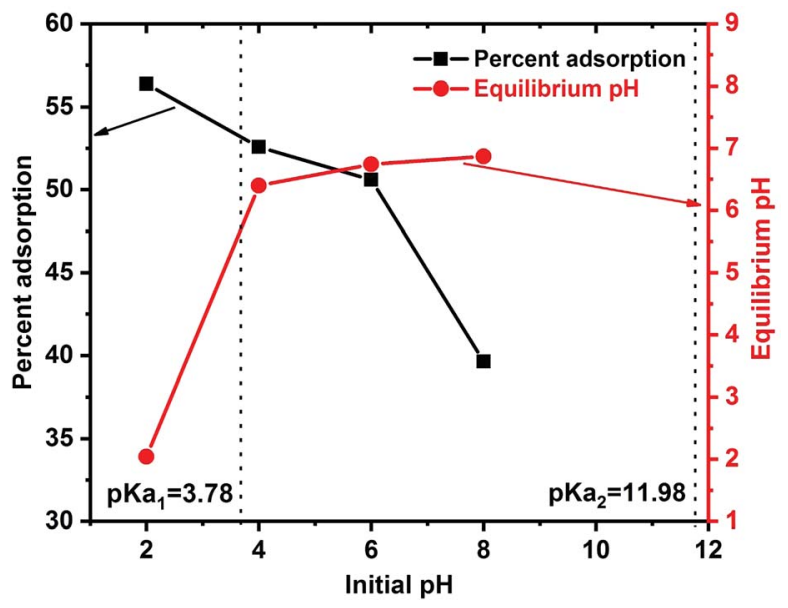

Fig. 7 Effect of $\mathrm{pH}$ on carbofuran removal by SB500.

Both the physical and the chemical sorption mechanisms are possible between carbofuran and biochar. ${ }^{27}$ The oxygencontaining functional groups present on the biochar surface are evident in the FTIR spectrum of the starting biochar (Fig. 6). These oxygen-containing functional groups, such as phenolic, hydroxyl, ether, quinoid, lactone and possibly some carboxylic acid oxygens, of biochar can form H-bonds with carbofuran. A few sample representations of the $\mathrm{H}$-bonding of the protonated and neutral carbofuran with biochar at different $\mathrm{pH}$ values are provided in Scheme 2.

The surface - $\mathrm{OH}$ groups on biochar act as $\mathrm{H}$-donors to carbofuran, as shown in Scheme 3. Moreover, the H-bond donation by the carbofuran $\mathrm{N}-\mathrm{H}$ group to the biochar oxygen functionalities is shown.

However, at high $\mathrm{pH}$, both the ionizable $-\mathrm{OH}$ functional groups of biochar are deprotonated and negatively charged. As

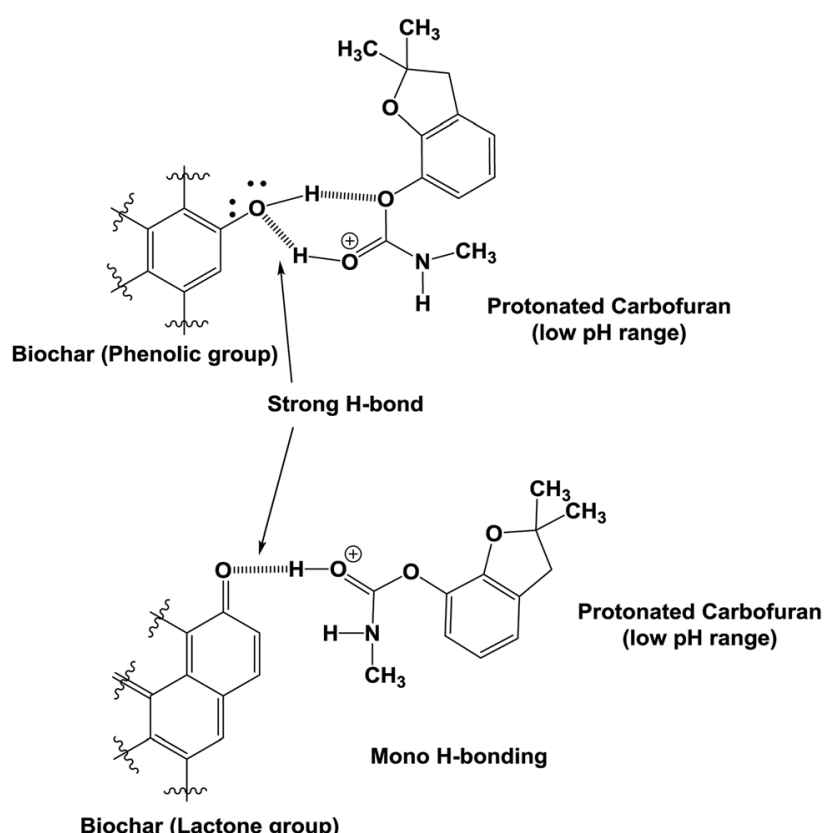

Scheme 2 Hydrogen bonding of the protonated and neutral carbofuran with biochar.
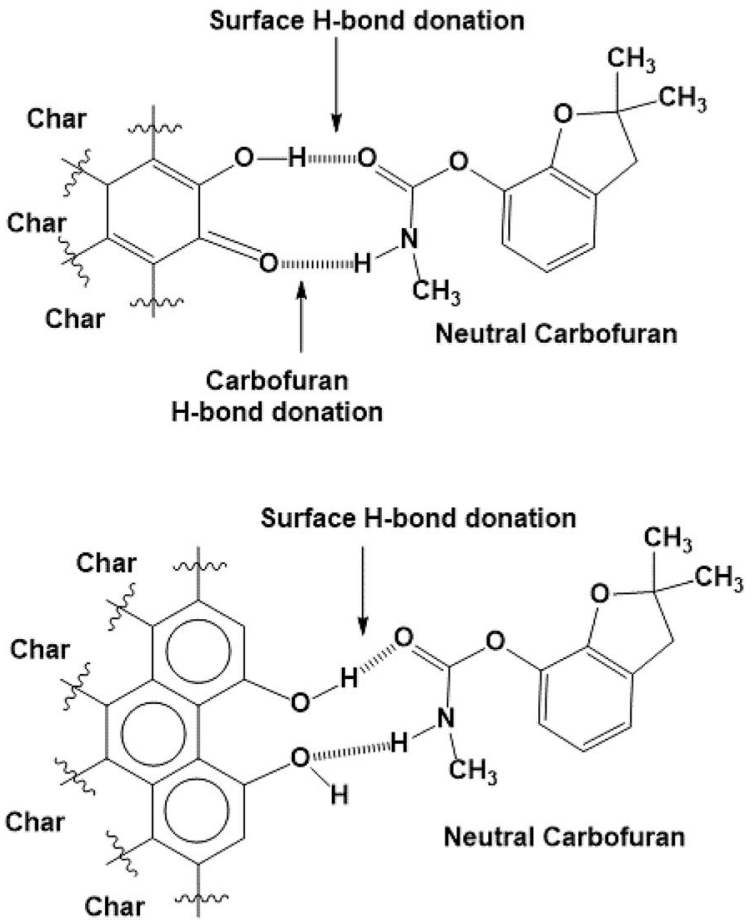

Scheme 3 Chelation showing the types of bonding that might occur if sterically possible.

$\mathrm{pH}$ increases, $-\mathrm{OH}$ groups present on biochar's surface deprotonate, forming sites that the $-\mathrm{NH}$ functional group of carbofuran can form H-bonds more strongly (Scheme 4).

Carbofuran sorption onto biochar through $\pi-\pi$ electron donoracceptor interactions can occur. ${ }^{28,29}$ Such $\pi-\pi$ electron donoracceptor interactions are well known for the sorption of organic contaminants onto carbonaceous activated carbons and biochars. In the acidic medium, the protonated carbofuran can interact with the electron rich regions of graphene-like surfaces of SB500, giving rise to strong $\pi-\pi$ electron donor-acceptor interactions, as shown in Scheme 5, where the protonated carbofuran is the $\pi$-electron acceptor. ${ }^{29}$ Similar results were reported for carbofuran adsorption on activated carbon, ${ }^{30,75}$ and fertilizer and steel industry wastes. ${ }^{76}$ Moreover, similar trends were reported for atrazine and simazine removal using biochar. ${ }^{77}$

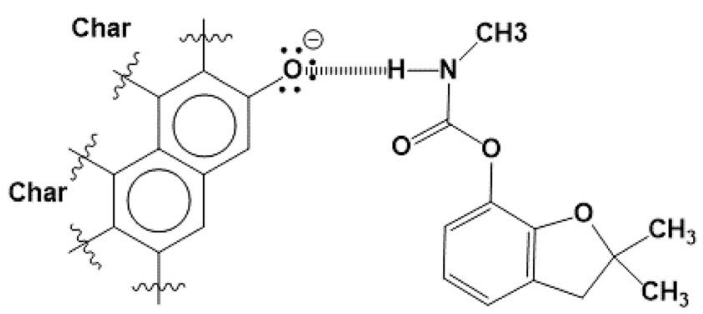

Biochar

Scheme 4 At high $\mathrm{pH},-\mathrm{OH}$ groups present on biochar's surface deprotonate, forming sites to which the $-\mathrm{NH}$ functional group of carbofuran can form $\mathrm{H}$-bonds. 


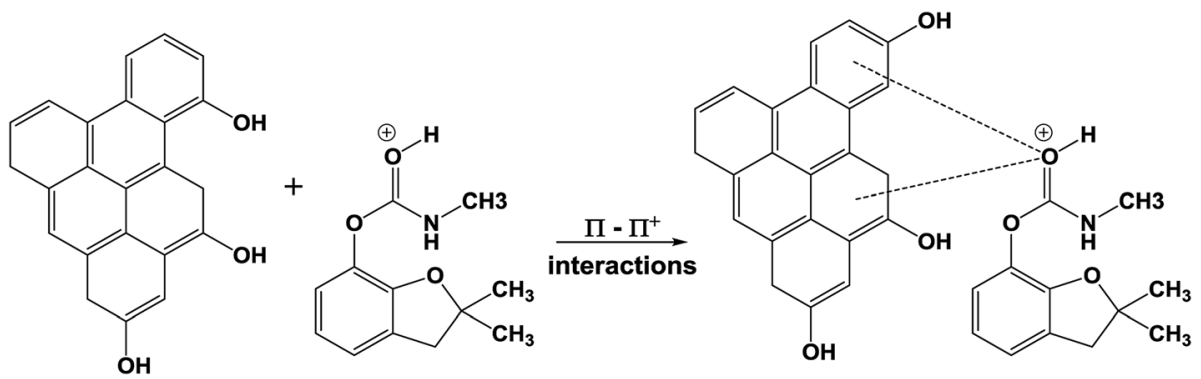

Scheme 5 Carbofuran sorption onto biochar via $\pi-\pi$ electron donor-acceptor interactions.

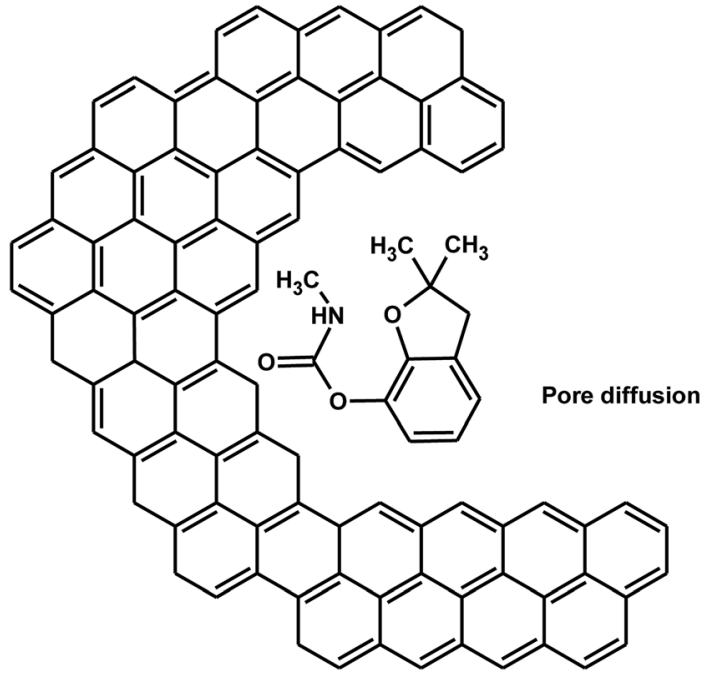

Scheme 6 Carbofuran diffusion into biochar pores [benzene rings on the left side show the biochar's aromatic structure].

Carbofuran diffusion into the biochar pores also contributes to its sorption. ${ }^{29}$ The high BET surface area of SB500 due to the micro-, meso-, and macro-pores can greatly assist in carbofuran adsorption. Carbofuran easily diffuses into the biochar pores (Scheme 6). Thus, both physisorption and chemisorption interactions are possible during carbofuran sorption.

At strongly basic $\mathrm{pH}$, both the surface groups of biochar are negative and carbofuran's $N-\mathrm{H}$ is removed to give an anion at the second $\mathrm{p} K_{\mathrm{a}}\left(\mathrm{p} K_{\mathrm{a}_{2}}=11.97\right)$, and only repulsions exist (Scheme 7).

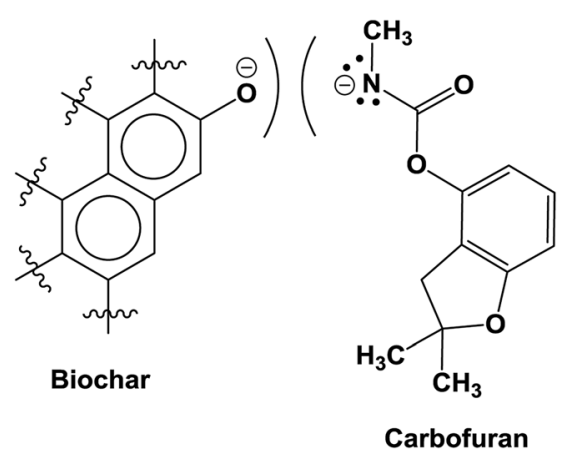

Scheme 7 Repulsion between biochar and carbofuran at strongly basic $\mathrm{pH}$.

\subsection{Carbofuran removal kinetics}

Carbofuran sorption kinetics was studied to determine the effect of equilibrium time on carbofuran removal at different adsorbate and adsorbent concentrations.

3.3.1 Effect of SB500 dose on carbofuran removal. The effect of SB500 quantity on aqueous carbofuran removal is shown in Fig. SM1 (ESI $\dagger$ ). The percent carbofuran removal increased from 16 to $32 \%$ with an increase in the SB500 dose from 1 to $2 \mathrm{~g} \mathrm{~L}^{-1}$ at an initial carbofuran concentration of $10 \mathrm{mg} \mathrm{L}^{-1}$. With a further increase in the SB500 dose from 2 to $4 \mathrm{~g} \mathrm{~L}^{-1}$, the carbofuran removal increased to $46 \%$. Thus, a $2 \mathrm{~g} \mathrm{~L}^{-1}$ dose of SB500 was treated as optimum for all the equilibrium and kinetic studies.

3.3.2 Effect of adsorbate concentration on carbofuran removal. The effect of initial adsorbate concentration on carbofuran removal by SB500 is shown in Fig. SM2 (ESI $\dagger$ ). The adsorption capacity increased from 6 to $8 \mathrm{mg} \mathrm{g}^{-1}$ with an increase in the initial concentration of carbofuran from 5 to $20 \mathrm{mg} \mathrm{L}{ }^{-1}$. Carbofuran removal kinetics was fast in the beginning, which gradually slowed down. This may be due to a larger number of sites available in the beginning as compared to the case of the later stages. ${ }^{75}$

Carbofuran adsorption dynamic data were modeled to the pseudo-first-order ${ }^{78}$ (eqn (SM1) $\dagger$ ) and pseudo-second order ${ }^{79}$ (eqn $(\mathrm{SM} 2) \dagger$ ) rate equations.

The first order rate equation did not fit to the sorption kinetic data (Tables SM1 and SM2 $\dagger$ ). The second order rate equation fit the data very well. The second order linear plots $\left(t / q_{t}\right.$ versus $t$ ) are shown in Fig. SM3 and SM4. $\dagger$ The kinetic parameters and correlation coefficients $R^{2}$ obtained from the second order rate plots at different adsorbent and adsorbate concentrations are given in Tables SM1 and SM2 (ESI $\dagger$ ). Furthermore, the experimental $q_{\mathrm{e}}$ values and the $q_{\mathrm{e}}$ values obtained from the pseudo second order equation are in close agreement. Similar results were reported for 2,4-D and carbofuran adsorption on different adsorbents. ${ }^{76}$

\subsection{Equilibrium sorption studies}

Equilibrium studies were carried out at 25,35 , and $45{ }^{\circ} \mathrm{C}$ in order to determine the temperature effect on carbofuran adsorption (Fig. SM5 $\dagger$ ). All the isotherms were concave and regular to the equilibrium concentration axis. Carbofuran removal increased with a decrease in the temperature. The 


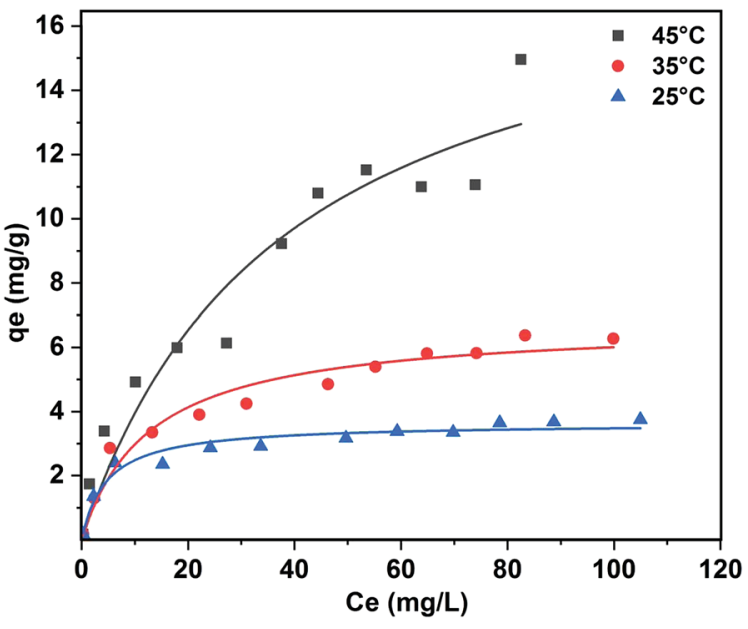

Fig. 8 Langmuir adsorption isotherms of carbofuran removal by SB500 at different temperatures $\left[\mathrm{pH} 6.0\right.$; SB500 dose $=2 \mathrm{~g} \mathrm{~L}^{-1}$; carbofuran concentration range $=1-100 \mathrm{mg} \mathrm{L}^{-1}$; particle size $=30-50$ BSS mesh]. Solid lines represent the data fitted to the Langmuir isotherm model.

Table 2 Freundlich, Langmuir and Temkin isotherm parameters for carbofuran removal using SB500 at different temperatures

Isotherm

parameters

$25{ }^{\circ} \mathrm{C}$

$35{ }^{\circ} \mathrm{C}$

$45{ }^{\circ} \mathrm{C}$

Freundlich isotherm

$K_{\mathrm{F}}\left(\mathrm{mg} \mathrm{g}^{-1}\right)$

$1 / n$

$R^{2}$

1.150

0.262

1.240

0.363

0.933

0.974

6.782

0.078

0.214

0.951

0.958

18.91

0.027

$B$
$R^{2}$

Temkin isotherm

$b_{\mathrm{Te}}\left(\mathrm{kJ} \mathrm{mol}^{-1}\right)$

$a_{\mathrm{Te}}\left(\mathrm{L} \mathrm{mg}^{-1}\right)$

$R^{2}$

1801.48

1008.99

2.287

4.769

0.955
1.350

0.522

0.955
Table 3 Thermodynamic parameters for carbofuran adsorption by SB500

\begin{tabular}{lllll}
\hline$-\Delta G^{\circ}\left(\mathrm{kJ} \mathrm{mol}^{-1}\right)$ & & & \\
\hline $25{ }^{\circ} \mathrm{C}$ & $35{ }^{\circ} \mathrm{C}$ & $45{ }^{\circ} \mathrm{C}$ & & $\begin{array}{l}\Delta H^{\circ} \\
\left(\mathrm{kJ} \mathrm{mol}^{-1}\right)\end{array}$
\end{tabular}

Freundlich equation range between 0 and 1 , showing the increased heterogeneity in the sorption process with the increase in temperature. More is the heterogeneity of the surface, the closer are the $1 / n$ values to zero. ${ }^{\mathbf{8 0}, \mathbf{8 1}}$

\subsection{Thermodynamic parameters}

Thermodynamic parameters $\left(\Delta H^{\circ}, \Delta S^{\circ}\right.$, and $\left.\Delta G^{\circ}\right)$ for carbofuran adsorption on SB500 were calculated using eqn (2) and (3) (Table 3). The negative $\Delta G^{\circ}$ values show the carbofuran adsorption feasibility and spontaneous nature. Enthalpy change $\left(\Delta H^{\circ}\right)$ and entropy change $\left(\Delta S^{\circ}\right)$ were calculated from the slope and intercept, respectively, of the van't Hoff plots ( $\ln K$ versus $1 / T$ ). The positive $\Delta H^{\circ}$ values indicate that carbofuran uptake on SB500 is endothermic. The positive $\Delta S^{\circ}$ values show the carbofuran affinity towards SB500 and an increase in the randomness at the solid-liquid interface during carbofuran uptake. The positive $\Delta H^{\circ}$ values were also recorded for carbofuran adsorption on banana stalks-activated carbon ${ }^{74}$ and for 2,4-D adsorption on date seeds-activated carbon. ${ }^{\mathbf{2}}$

\subsection{Fixed-bed adsorber design}

The batch studies provide information about the adsorbent effectiveness in terms of maximum uptake per unit of sorbent, $\mathrm{pH}$, and adsorbent particle size. ${ }^{83}$ The parameters derived from the batch studies are helpful in designing a fixed-bed that is more practical and applicable in establishing an adsorption process. The breakthrough curve expressed in terms of $C / C_{\mathrm{o}}$ versus carbofuran volume passed through the column is shown in Fig. 9. The fixed-bed design parameters were calculated using eqn (4)-(13). These parameters are given in Table 4.

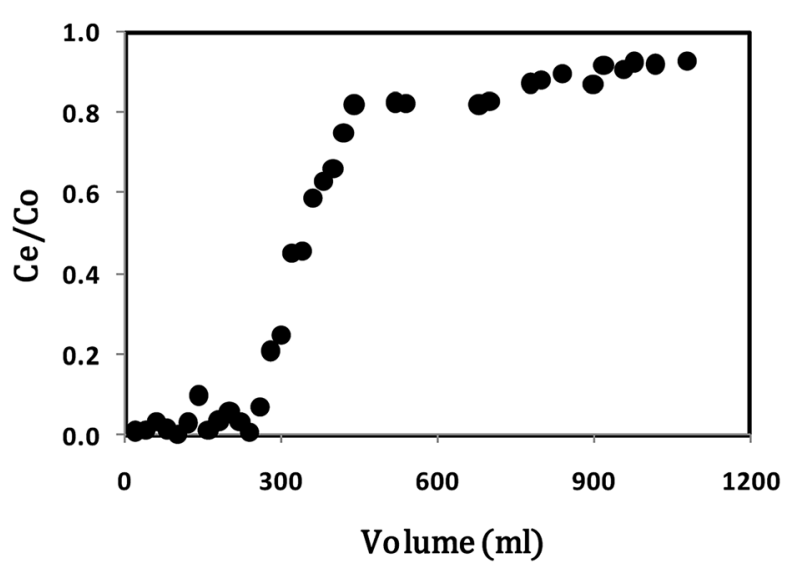

Fig. 9 Breakthrough curve for carbofuran adsorption on SB500 at the flow rate of $1 \mathrm{~mL} \mathrm{~min}{ }^{-1}$. 
Table 4 Fixed-bed design parameters for carbofuran adsorption on SB500

\begin{tabular}{ll}
\hline Parameters & Values \\
\hline$C_{\mathrm{o}}\left(\mathrm{mg} \mathrm{mL}^{-1}\right)$ & 0.0046 \\
$C_{\mathrm{x}}\left(\mathrm{mg} \mathrm{mL}^{-1}\right)$ & 0.0427 \\
$C_{\mathrm{b}}\left(\mathrm{mg} \mathrm{mL}^{-1}\right)$ & 0.0028 \\
$V_{\mathrm{x}}\left(\mathrm{mg} \mathrm{cm}^{-2}\right)$ & 0.3809 \\
$V_{\mathrm{b}}\left(\mathrm{mg} \mathrm{cm}^{-2}\right)$ & 58.7465 \\
$\left.F_{\mathrm{m}}(\mathrm{mg} \mathrm{cm})^{-2} \mathrm{~min}^{-1}\right)$ & 0.054 \\
$D(\mathrm{~cm})$ & 13 \\
$t_{\mathrm{x}}(\mathrm{min})$ & 1080 \\
$t_{\delta}(\mathrm{min})$ & 1073 \\
$t_{\mathrm{b}}(\mathrm{min})$ & 280 \\
$F$ & 0.7390 \\
$\delta(\mathrm{cm})$ & 9.6296 \\
Percent saturation & 80.67 \\
Biochar usage rate $\left(\mathrm{kg} \mathrm{L}^{-1}\right)$ & 21.4286 \\
EBCT $(\mathrm{min})$ & 40.82 \\
Breakthrough capacity $\left(\mathrm{mg} \mathrm{g}^{-1}\right)$ & 0.188 \\
Column capacity $\left(\mathrm{mg} \mathrm{g}^{-1}\right)$ & 0.30 \\
\end{tabular}

Based on the fixed-bed design parameters obtained from this column run, it can be concluded that biochar requires a slow flow rate to ensure long residence or contact time. The use of more than one column in series can lead to better results.

\subsection{Desorption studies}

Desorption studies were carried out to recover carbofuran with simultaneous regeneration of the exhausted biochar. Ethanol was used as an eluent in $10 \mathrm{~mL}$ increments for carbofuran desorption.

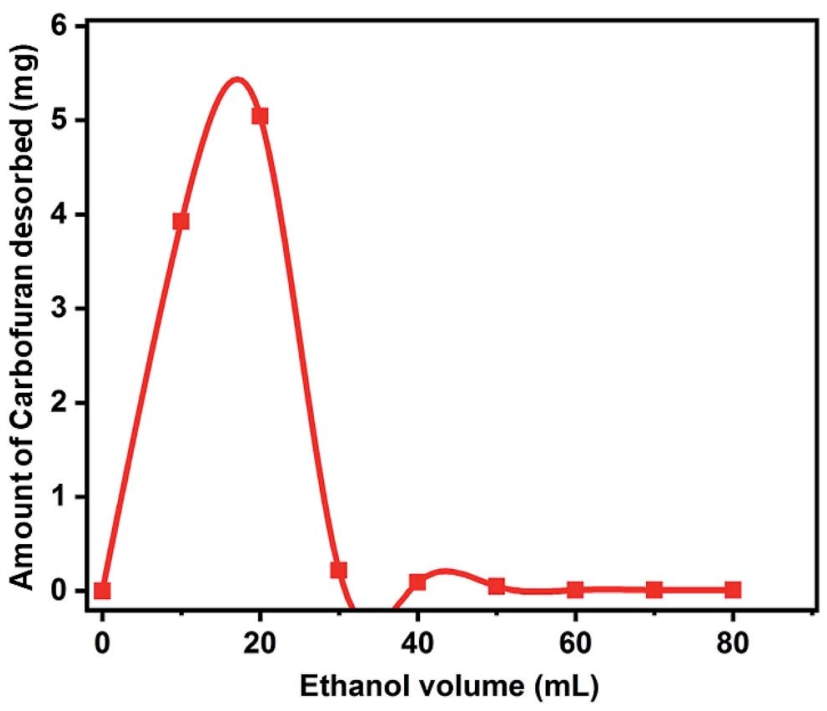

Fig. 10 Carbofuran desorption from SB500.

Almost $96 \%$ of total carbofuran was desorbed using $20 \mathrm{~mL}$ ethanol (Fig. 10).

\subsection{Comparative evaluation of the developed biochar vis- à-vis other adsorbents}

Different adsorbents including agricultural by-products, industrial wastes, activated carbons (ACs), and biochars have

Table 5 Adsorption capacities of sugarcane bagasse biochar (SB500) vis-à-vis other adsorbents

\begin{tabular}{|c|c|c|c|c|c|c|}
\hline Adsorbents & Temp $\left({ }^{\circ} \mathrm{C}\right)$ & $\begin{array}{l}\text { Conc. range } \\
\left(\mathrm{mg} \mathrm{L}^{-1}\right)\end{array}$ & $\begin{array}{l}\text { Adsorption capacity } \\
\left(\mathrm{mg} \mathrm{g}^{-1}\right)\end{array}$ & $\begin{array}{l}\text { Surface area } \\
\left(\mathrm{m}^{2} \mathrm{~g}^{-1}\right)\end{array}$ & $\begin{array}{l}\text { Adsorption capacity } \\
\text { per surface area }\end{array}$ & Ref. \\
\hline \multirow[t]{3}{*}{ Sugarcane bagasse biochar (SB500) } & 25 & \multirow[t]{3}{*}{$1-100$} & 3.7 & \multirow[t]{3}{*}{148} & 0.02 & \multirow[t]{3}{*}{ This study } \\
\hline & 35 & & 6.8 & & 0.04 & \\
\hline & 45 & & 18.9 & & 0.13 & \\
\hline Rice husk biochar (RHBC300) & 30 & \multirow[t]{4}{*}{$5-100$} & 30.73 & 69 & 0.45 & \multirow[t]{4}{*}{27} \\
\hline Rice husk biochar (RHBC500) & 30 & & 48.75 & 170 & 0.29 & \\
\hline Rice husk biochar (RHBC700) & 30 & & 132.87 & 237 & 0.56 & \\
\hline Rice husk biochar (RHBC700S) & 30 & & 160.77 & 252 & 0.64 & \\
\hline Tea waste biochar (TWBC300) & 30 & \multirow[t]{3}{*}{$5-100$} & 54.71 & 2.3 & 23.99 & \multirow[t]{3}{*}{28} \\
\hline Tea waste biochar (TWBC500) & 30 & & 48.73 & 1.6 & 31.04 & \\
\hline Tea waste biochar (TWBC700) & 30 & & 22.74 & 342 & 0.06 & \\
\hline Tea waste biochar (TWBC700) & 25 & \multirow[t]{2}{*}{50} & 10.74 & 342 & 0.03 & \multirow[t]{2}{*}{29} \\
\hline Rice husk biochar (RHBC700) & 25 & & 23.86 & 377 & 0.06 & \\
\hline Blast furnace dust & 25 & \multirow[t]{5}{*}{$22-110$} & 13.0 & 13 & 1.00 & \multirow[t]{5}{*}{76} \\
\hline Blast furnace sludge & 25 & & 23.0 & 28 & 0.80 & \\
\hline Activated carbon & 25 & & 266.0 & 710 & 0.37 & \\
\hline \multirow[t]{2}{*}{ Carbonaceous adsorbent } & 25 & & 208.3 & 380 & 0.29 & \\
\hline & 45 & & 150.2 & 380 & 0.39 & \\
\hline Granular activated carbon (GAC) & 30 & $50-225$ & 96.1 & 732 & 0.13 & 84 \\
\hline \multirow[t]{3}{*}{ Banana stalk activated carbon } & 30 & \multirow[t]{3}{*}{$25-250$} & 156.3 & 981 & 0.16 & \multirow[t]{3}{*}{85} \\
\hline & 40 & & 161.3 & & 0.16 & \\
\hline & 50 & & 164.0 & & 0.17 & \\
\hline Date seed activated carbon & 30 & $25-250$ & 137.0 & 880 & 0.15 & 26 \\
\hline Commercial activated carbon & 30 & $25-250$ & 97.1 & 620 & 0.50 & 75 \\
\hline Palm fronds activated carbon & 30 & $25-250$ & 164.0 & 1237 & 0.13 & 30 \\
\hline \multirow[t]{3}{*}{ Coconut frond activated carbon (CFAC) } & 30 & \multirow[t]{3}{*}{$25-250$} & 198.4 & 484 & 0.41 & \multirow[t]{3}{*}{86} \\
\hline & 40 & & 193.1 & & 0.39 & \\
\hline & 50 & & 205.0 & & 0.42 & \\
\hline
\end{tabular}


been used for carbofuran removal (Table 5). In general, activated carbons show higher removal capacities compared to biochars and adsorbents. This may be due to the high surface area of the activated carbons. Furthermore, the sugarcane bagasse biochar shows comparable performance compared to other biochars applied for carbofuran removal (Table 5). The removal capacity per unit surface area of SB500 is also comparable to many adsorbents including activated carbons (Table 5).

\section{Conclusions}

Herein, slowly pyrolyzed biochar obtained from sugarcane bagasse (SB500) was successfully used for aqueous carbofuran remediation. The solution $\mathrm{pH}$ played an important role in carbofuran adsorption. The maximum adsorption was achieved at pH 2.0. The equilibrium sorption data were best fitted to the Langmuir equation. The maximum monolayer adsorption capacity of $19 \mathrm{mg} \mathrm{g}^{-1}$ was achieved at $45{ }^{\circ} \mathrm{C}$. The carbofuran adsorption kinetics data were fitted best to the pseudo-second order rate equation. $\Delta G^{\circ}, \Delta H^{\circ}$, and $\Delta S^{\circ}$ values were determined. Sugarcane bagasse biochar (SB500) was compared with other adsorbents used for carbofuran removal. Overall, the performance of SB500 was comparable to that of many adsorbents previously used for carbofuran remediation. The recovery of carbofuran with simultaneous SB500 regeneration was also successfully achieved. Thus, sustainable sugarcane bagasse biochar may be considered for water decontamination to replace the costly activated carbons and other commercially available adsorbents.

\section{Conflicts of interest}

There are no conflicts to declare.

\section{Acknowledgements}

Financial support [DST/TM/WTI/2K15/121(C) dated: 19.09.2016] in the project entitled "Removal and Recovery of Pharmaceuticals from water using sustainable magnetic and nonmagnetic biochars" from Department of Science and Technology, New Delhi, India is thankfully acknowledged. Financial support (No. INTISL/12/P-008) in the project entitled "Development of Rice and Tea Residues-Derived Bio-Chars as Effective Green Materials for Adsorptive Stabilization of Pesticides in Soil and Water Systems" is also thankfully acknowledged. Financial support [DST/IS-STAC/CO2-SR-129/12(G)] from Department of Science and Technology, New Delhi, India is thankfully acknowledged. Authors are also thankful to University Grant Commission (UGC), New Delhi, for providing the financial assistance under 21st Century Indo-US Research Initiative 2014 to Jawaharlal Nehru University, New Delhi and Mississippi State University, USA in the project "Clean Energy and Water Initiatives" [UGC No. F.194-1/2014(IC)]. One of the authors (V. V.) thankfully acknowledges University Grants Commission, New Delhi, India for the Research Fellowship. One of the authors (DM) also thanks Jawaharlal Nehru University for providing financial assistance under the Second phase of a University with Potential of Excellence (UPOEII) grant (ID 189). MP is thankful to CSIR for providing financial assistance under CSIR-SRF. DM is also acknowledging the funding support from DST PURSE, Government of India. Authors are thankful to Advance Instrumentation Research Facility (AIRF), Jawaharlal Nehru University, New Delhi for allowing us to use XRD, FTIR, and SEM facilities for biochar characterization.

\section{References}

1 P. Goel, Water pollution: causes, effects and control, New Age International Publishers, New Delhi, New Delhi, 2nd edn, 2006.

2 I. A. Shiklomanov and J. C. Rodda, World water resources at the beginning of the twenty-first century, Cambridge University Press, Cambridge, 2003.

$3 \mathrm{~W}$. H. Organization, Water pollution control: a guide to the use of water quality management principles, World Health Organization/United Nations Environment Programme, London, 1997.

4 J. Zolgharnein, A. Shahmoradi and J. Ghasemi, Clean: Soil, Air, Water, 2011, 39, 1105-1119.

5 N. L. Devi and P. Raha, Bulletin of Environmental and Scientific Research, 2013, 2, 9-14.

6 A. Agrawal, R. S. Pandey and B. Sharma, J. Water Resour. Prot., 2010, 2, 432.

7 S. Donovan, M. Taggart and N. Richards, in Carbofuran and Wildlife Poisoning: Global Perspectives and Forensic Approaches, ed. N. Richards, UK, John Wiley \& Sons, Inc, 2012, ch. 1, pp. 1-18.

8 P. Plangklang and A. Reungsang, Process Biochem., 2010, 45, 230-238.

9 E. Hodgson, R. M. Roe and N. Motoyama, Reviews in pesticide toxicology, USA, 1991.

10 D. M. Trotter, R. A. Kent and M. P. Wong, Crit. Rev. Environ. Sci. Technol., 1991, 21, 137-176.

11 J. Massoulie and S. Bon, Annu. Rev. Neurosci., 1982, 5, 57106.

12 P. Ott, Biochim. Biophys. Acta, Biomembr., 1985, 822, 375-392. 13 T. R. Fukuto, Environ. Health Perspect., 1990, 87, 245-254.

14 USEPA, National Primary Drinking Water Regulations, https:// www.epa.gov/ground-water-and-drinking-water/nationalprimary-drinking-water-regulations\#one.

15 R. C. Gupta, J. Toxicol. Environ. Health, Part A, 1994, 43, 383418.

16 M. E. DeLorenzo, G. I. Scott and P. E. Ross, Environ. Toxicol. Chem., 2001, 20, 84-98.

17 D. Tenenbaum, Environ. Health Perspect., 2008, 116, A425.

18 M. Mahalakshmi, B. Arabindoo, M. Palanichamy and V. Murugesan, J. Hazard. Mater., 2007, 143, 240-245.

19 L.-A. Lu, Y.-S. Ma, M. Kumar and J.-G. Lin, Sustainable Environ. Res., 2010, 20, 293-297.

20 W. Kuo, Y. Chiang and L. Lai, J. Environ. Sci. Health, Part B, 2006, 41, 937-948.

21 Y.-S. Ma, C.-F. Sung and J.-G. Lin, J. Hazard. Mater., 2010, 178, 320-325. 
22 F. J. Benitez, J. L. Acero and F. J. Real, J. Hazard. Mater., 2002, 89, 51-65.

23 E. Enjarlis, S. Bismo, S. Slamet and R. W. Soemantojo, $14^{\text {th }}$ Regional Symposium of Chemical Engineering, Chemical Engineering Department, Gadjah Mada University, Yogyakarta, Indonesia, 2007, ISBN 978-979-16978-0-4.

24 I. Hua and U. Pfalzer-Thompson, Water Res., 2001, 35, 14451452.

25 M. Z. Bueno, L. A. Coral, M. L. Sens and F. R. Lapolli, Eng. Sanit. Ambiental, 2016, 21, 447-458.

26 J. Salman, V. Njoku and B. Hameed, Chem. Eng. J., 2011, 173, 361-368.

27 S. Mayakaduwa, I. Herath, Y. S. Ok, D. Mohan and M. Vithanage, Environ. Sci. Pollut. Res., 2017, 24, 2275522763.

28 S. Mayakaduwa, M. Vithanage, A. Karunarathna, D. Mohan and Y. S. Ok, Chem. Speciation Bioavailability, 2016, 28, 110-118.

29 M. Vithanage, S. Mayakaduwa, I. Herath, Y. S. Ok and D. Mohan, Chemosphere, 2016, 150, 781-789.

30 J. M. Salman, Journal of Chemistry, 2013, 2013, 1-5.

31 D. Kołodyńska, R. Wnętrzak, J. Leahy, M. Hayes, W. Kwapiński and Z. Hubicki, Chem. Eng. J., 2012, 197, 295-305.

32 D. Mohan, A. Sarswat, Y. S. Ok and C. U. Pittman Jr, Bioresour. Technol., 2014, 160, 191-202.

33 M. Patel, R. Kumar, K. Kishor, T. Mlsna, C. U. Pittman Jr and D. Mohan, Chem. Rev., 2019, 119, 3510-3673.

34 M. Ahmad, A. U. Rajapaksha, J. E. Lim, M. Zhang, N. Bolan, D. Mohan, M. Vithanage, S. S. Lee and Y. S. Ok, Chemosphere, 2014, 99, 19-33.

35 D. Mohan, C. U. Pittman Jr and P. H. Steele, Energy Fuels, 2006, 20, 848-889.

36 D. Mohan, C. U. Pittman Jr, M. Bricka, F. Smith, B. Yancey, J. Mohammad, P. H. Steele, M. F. Alexandre-Franco, V. Gómez-Serrano and H. Gong, J. Colloid Interface Sci., 2007, 310, 57-73.

37 D. Mohan, R. Sharma, V. K. Singh, P. Steele and C. U. Pittman Jr, Ind. Eng. Chem. Res., 2012, 51, 900-914.

38 N. B. Dewage, A. S. Liyanage, C. U. Pittman Jr, D. Mohan and T. Mlsna, Bioresour. Technol., 2018, 263, 258-265.

39 N. B. Dewage, A. S. Liyanage, Q. Smith, C. U. Pittman Jr, F. Perez, E. B. Hassan, D. Mohan and T. Mlsna, Chemosphere, 2019, 225, 943-953.

40 A. G. Karunanayake, O. AdeleTodd, M. Crowley, L. Ricchetti, C. U. Pittman Jr, R. Anderson, D. Mohan and T. Mlsna, Chem. Eng. J., 2018, 331, 480-491.

41 N. B. Dewage, R. E. Fowler, C. U. Pittman Jr, D. Mohan and T. Mlsna, RSC Adv., 2018, 8, 25368-25377.

42 M. Essandoh, D. Wolgemuth, C. U. Pittman Jr, D. Mohan and T. Mlsna, Chemosphere, 2017, 174, 49-57.

43 A. A. Oladipo, A. O. Ifebajo and R. Vaziri, Green Adsorbents for Pollutant Removal, 2018, pp. 327-351.

44 M. Gazi, A. A. Oladipo and K. A. Azalok, Sep. Sci. Technol., 2018, 53, 1124-1131.

45 C. Peiris, S. R. Gunatilake, T. E. Mlsna, D. Mohan and M. Vithanage, Bioresour. Technol., 2017, 246, 150-159.
46 A. A. Oladipo and A. O. Ifebajo, J. Environ. Manage., 2018, 209, 9-16.

47 A. Sarswat and D. Mohan, RSC Adv., 2016, 6, 85390-85410.

48 D. Mohan, K. Abhishek, A. Sarswat, M. Patel, P. Singh and C. U. Pittman Jr, RSC Adv., 2018, 8, 508-520.

49 MNRE, Ministry of New and Renewable Energy, 2009, https:// mnre.gov.in/biomass-powercogen.

50 AGRICOOP, Agriculture Statistics at a glance 2010, Directorate of Economics and Statistics, Ministry of Agriculture, Govt. of India, http://agricoop.nic.in/Agristatistics.htm.

51 M. Hiloidhari, D. Das and D. C. Baruah, Renewable Sustainable Energy Rev., 2014, 32, 504-512.

52 V. Gupta, I. Ali and D. Mohan, J. Colloid Interface Sci., 2003, 265, 257-264.

53 NIST Chemistry WebBook, NIST Standard Reference Database Number 69, ed. P. J. Linstrom and W. G. Mallard, National Institute of Standards and Technology, Gaithersburg MD, 20899, retrieved August 2, 2019, DOI: 10.18434/T4D303.

54 R. Sharma, A. Sarswat, C. U. Pittman Jr and D. Mohan, RSC Adv., 2017, 7, 8606-8624.

55 L. C. Melo, A. R. Coscione, C. A. Abreu, A. P. Puga and O. A. Camargo, BioResources, 2013, 8, 4992-5004.

56 Z. Liu, F.-S. Zhang and J. Wu, Fuel, 2010, 89, 510-514.

57 M. Ertaș and M. H. Alma, J. Anal. Appl. Pyrolysis, 2010, 88, 22-29.

58 K. H. Kim, J.-Y. Kim, T.-S. Cho and J. W. Choi, Bioresour. Technol., 2012, 118, 158-162.

59 D. Govindarajan and G. Jayalakshmi, Adv. Appl. Sci. Res., 2011, 2, 544-549.

60 K. Jindo, H. Mizumoto, Y. Sawada, M. A. Sanchez-Monedero and T. Sonoki, Biogeosciences, 2014, 11, 6613-6621.

61 S. Y. Oh, D. I. Yoo, Y. Shin, H. C. Kim, H. Y. Kim, Y. S. Chung, W. H. Park and J. H. Youk, Carbohydr. Res., 2005, 340, 23762391.

62 B. Chen and Z. Chen, Chemosphere, 2009, 76, 127-133.

63 R. Sharma, J. Wooten, V. Baliga and M. Hajaligol, Fuel, 2001, 80, 1825-1836.

64 R. Panda, M. Hsieh, R. Chung and T. Chin, J. Phys. Chem. Solids, 2003, 64, 193-199.

65 S. Mozia, M. Tomaszewska and A. W. Morawski, Water Res., 2005, 39, 501-509.

66 M. I. Schnitzer, C. M. Monreal, G. A. Facey and P. B. Fransham, J. Environ. Sci. Health, Part B, 2007, 42, 7177.

67 M. Tatzber, M. Stemmer, H. Spiegel, C. Katzlberger, G. Haberhauer, A. Mentler and M. H. Gerzabek, J. Plant Nutr. Soil Sci., 2007, 170, 522-529.

68 A. K. Sarmah, P. Srinivasan, R. J. Smernik, M. Manley-Harris, M. J. Antal, A. Downie and L. van Zwieten, Soil Res., 2010, 48, 648-658.

69 X. Chen, G. Chen, L. Chen, Y. Chen, J. Lehmann, M. B. McBride and A. G. Hay, Bioresour. Technol., 2011, 102, 8877-8884.

70 J.-H. Yuan, R.-K. Xu and H. Zhang, Bioresour. Technol., 2011, 102, 3488-3497.

71 B. B. Uzun, E. Apaydin-Varol, F. Ateş, N. Özbay and A. E. Pütün, Fuel, 2010, 89, 176-184. 
72 G. Haberhauer and M. Gerzabek, Vib. Spectrosc., 1999, 19, 413-417.

73 W.-K. Kim, T. Shim, Y.-S. Kim, S. Hyun, C. Ryu, Y.-K. Park and J. Jung, Bioresour. Technol., 2013, 138, 266-270.

74 J. Salman and B. Hameed, J. Hazard. Mater., 2010, 175, 133137.

75 J. Salman, F. Abd and A. Muhammed, Int. J. Chem. Sci., 2011, 9, 557-564.

76 V. K. Gupta, I. Ali and V. K. Saini, J. Colloid Interface Sci., 2006, 299, 556-563.

77 W. Zheng, M. Guo, T. Chow, D. N. Bennett and N. Rajagopalan, J. Hazard. Mater., 2010, 181, 121-126.

78 S. K. Lagergren, Sven. Vetenskapsakad. Handingarl., 1898, 24, 1-39.
79 Y.-S. Ho and G. McKay, Process Biochem., 1999, 34, 451-465. 80 K. Y. Foo and B. H. Hameed, Chem. Eng. J., 2010, 156, 2-10. 81 G. McKay, Use of Adsorbents for the Removal of Pollutants from Wastewater, CRC Press, 1995.

82 J. M. Salman and K. A. Al-Saad, Int. J. Chem. Sci., 2012, 10, 677-690.

83 K. Low and C. Lee, Bioresour. Technol., 1991, 38, 1-6.

84 J. Salman and B. Hameed, Desalination, 2010, 256, 129-135.

85 J. Salman and B. Hameed, J. Hazard. Mater., 2010, 176, 814819.

86 V. Njoku, M. A. Islam, M. Asif and B. Hameed, J. Anal. Appl. Pyrolysis, 2014, 110, 172-180. 